\title{
Restoration of Degraded Moving Image for Predicting a Moving Object
}

\author{
Kei Akiyama Non-member (Nagoya University, RIKEN, k_akiyama@nuem.nagoya-u.ac.jp) \\ Zhi-wei Luo Non-member (Kobe University, RIKEN) \\ Masaki Onishi Member (AIST, RIKEN) \\ Shigeyuki Hosoe Member (RIKEN)
}

Keywords : moving image restoration, nonlinear optimization, dynamics of moving image, multiresolution wavelet analysis

There have been proposed many methods for image restoration, which estimates original images form degraded ones. However, many of them were for static images. In this paper, we propose a moving image restoration method based on the static image restoration method[1]. Since high computational cost such as an iterative calculation is required for the method in [1], much more computation cost will be need when we apply this method to moving image restoration. Consequently, we consider a class of moving image and propose an effective algorithm by utilizing the iterative calculation[1]. We model the dynamics of moving image and compute a restored moving image using a predicted image calculated based on the modeled dynamics.

The block diagram of our proposing algorithm at $k$ th frame is shown in Fig. 1. First, we transform a degraded image to the wavelet domain by multiresolution wavelet decomposition (MWD). By using this degraded image and a predicted image $\left(\hat{\boldsymbol{f}}_{p r d}^{[k]}\right)$ calculated in the predictor, we compute a restored image. The predicted image is calculated based on the dynamics of the moving object, which is extracted from the past restored images and predicted by Kalman filter. In the method of [1], the iterative restoration calculation is needed to obtain an optimal solution per each frame and hence the computation cost will be quite high when processing all frames. On the other hand, by using the predicted image, we can calculate a restored image near the optimal solution by only one time restoration calculation. Finally, we obtain a restoration result by multiresolution wavelet reconstruction (MWR).

We verified our proposed method by an artificial degraded moving image of $128 \times 128$ pixels degraded by a Gaussian convolution kernel and additive noise. We restored this degraded moving image by the proposed method, and compared the result with the two methods which gave a current degraded image or a previous restored image as predicted images. We call them compared method 1 and 2, respectively. These two methods do not make predictions on moving object. The restoration results of each

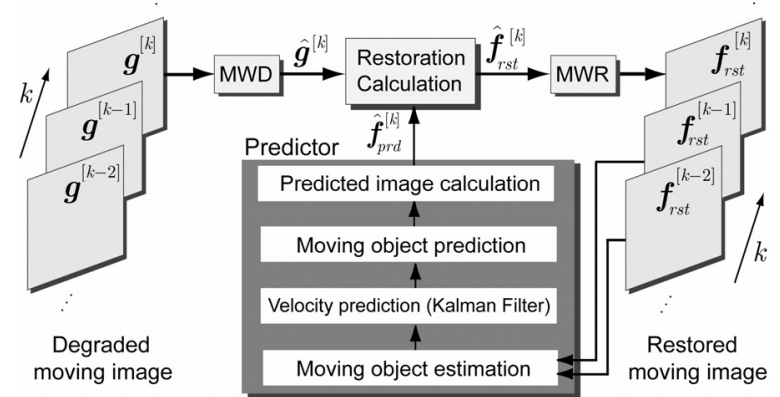

Fig. 1. Block diagram of the proposing method at $k$ th frame method are shown in Table 1. In the table, the average ISNR (Improved Signal-To-Noise Ratio) of our method is the nearest to the optimal result (method of (1)). Nevertheless, total calculation time is shortened to a large extent. Moreover, the total prediction time within the total calculation time is sufficiently short. By these results, we can conclude that the proposed method can achieve the restoration near optimal results in a short calculation time by making a prediction of the foreground.

We also show the results of proposed method for real moving image. We shot an optically-blurred video and calculate the restored moving image by our proposed method. Fig. 2 shows the degraded image (a) and its restored one (b) of 21 st frame. We can see that the entire patterns in the restored image became clearer than those in the degraded one. Therefore, we can make sure that the restored moving image has good quality by applying the proposed method. Similar performance has shown for other real moving images.

The proposed method can cope with various degradation factors, such as optical blur, low resolution, distortion, and so on. Some assumptions given in our algorithm can be relaxed or re- moved by improving the moving object extraction.

Table 1. Comparison of restoration results of an artificial moving image

\begin{tabular}{l|c|c|c|c}
\hline & $\begin{array}{c}\text { Proposed } \\
\text { method }\end{array}$ & $\begin{array}{c}\text { Compared } \\
\text { method 1 }\end{array}$ & $\begin{array}{c}\text { Compared } \\
\text { method 2 }\end{array}$ & $\begin{array}{c}\text { Method of } \\
{[1]}\end{array}$ \\
\hline $\begin{array}{l}\text { Average } \\
\text { ISNR[dB] }\end{array}$ & 2.286 & 2.198 & 2.236 & 2.301 \\
\hline $\begin{array}{l}\text { Total calculation } \\
\text { time }\end{array}$ & $22^{\prime} 43^{\prime \prime}$ & $21^{\prime} 45^{\prime}$ & $18^{\prime} 41^{\prime \prime}$ & $5: 55^{\prime} 20^{\prime \prime}$ \\
\hline $\begin{array}{l}\text { Total prediction } \\
\text { time }\end{array}$ & $7{ }^{\prime \prime} 19$ & - & - & - \\
\hline
\end{tabular}

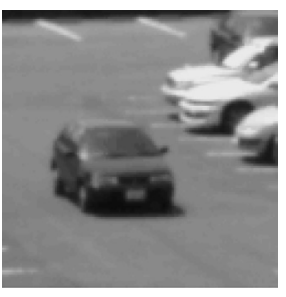

(a) Degraded image

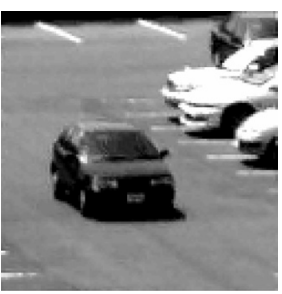

(b) Restored image
Fig. 2. Restoration result of the real moving image (21st frame)

\section{Reference}

(1) M. Belge, M.E. Kilmer, and E.L. Miller : "Wavelet Domain Image Restoration with Adaptive Edge-Preserving Regularization", IEEE Trans. on Image Processing, Vol. 9, No. 4, pp. 597-608 (2000) 


\title{
運動物体予測を用いた劣化動画像復元
}

\author{
非会員 秋山 圭*,** 非会員 羅 志偉***,** \\ 正 員 大西 正輝 ${ }^{* * * *, * *}$ 正 員 細江 繁幸**
}

\section{Restoration of Degraded Moving Image for Predicting a Moving Object}

Kei Akiyama*,**, Non-member, Zhi-wei Luo***,**, Non-member, Masaki Onishi****,**, Member, Shigeyuki Hosoe**, Member

Iterative optimal calculation methods have been proposed for degraded static image restoration based on the multiresolution wavelet decomposition. However, it is quite difficult to apply these methods to process moving images due to the high computation cost. In this paper, we propose an effective restoration method for degraded moving image by modeling the motion of a moving object and predicting the future object position. We verified our method by computer simulations and experiments to show that our method can achieve favorable results.

キーワード：動画像復元, 非線形最適化, 動画像ダイナミクス, 多重解像度ウェーブレット解析

Keywords: moving image restoration, nonlinear optimization, dynamics of moving image, multiresolution wavelet analysis

\section{1. まえがき}

低い解像度で得られた動画像や，観測ノイズあるいは大 気の摇らぎなどによって劣化した動画像に対し，目視によ る画質改善や後段の認識処理における精度向上のため, 動 画像から劣化要因を除去する必要がある。このような劣化 画像から真の画像を推定する画像復元問題は応用上極めて 重要であり, 従来は静止画像に関して盛んに研究が行われ てきた。特に，輪郭など画像の局所的な特徵を保持した画 像復元手法の提案が多くなされ(1) (3), 中でも多重解像度 ウェーブレット解析 ${ }^{(4)}$ を用いた静止画像復元方法 ${ }^{(3)}$ は, 画

\footnotetext{
$*$ 名古屋大学大学院工学研究科

干 464-8603 愛知県名古屋市千種区不老町

Graduate School of Engineering, Nagoya University

Furo-cho, Chikusa-ku, Nagoya, 464-8603, JAPAN

** 独立行政法人理化学研究所 バイオ・ミメテイックコントロール 研究センター

７ 463-0003 愛知県名古屋市守山区下志段味字穴ヶ洞 2271-130 Bio-Mimetic Control Research Center, RIKEN

2271-130 Anagahora, Shimoshidami, Moriyama-ku, Nagoya, 463-0003, JAPAN

*** 神戸大学工学部

于 657-8501 兵庫県神戸市灘区六甲台町 1-1

Faculty of Engineering, Kobe University 1-1 Rokkohdai-cho, Nada-ku, Kobe, 657-8501, JAPAN

**** 産業技術総合研究所 情報技術研究部門

干 305-8568 茨城県つくば市梅園 1-1-1 中央第 2

Information Technology Research Institute, National Institute of Advanced Industrial Science and Technology (AIST) 1-1-1 Umezono, Tsukuba, 305-8568, JAPAN
}

像の持つ特性に応じて復元パラメータを適応的に与えるこ とで, 良好な復元画像を得ている。近年になってノイズ除 去 (5) や欠陥補修 (6) などの動画像復元の研究が行われてい るが, これらの手法は解像度低下やぼけなど実環境で起こ りうる劣化要素を考慮していない。また, 複数フレームか ら高解像度の復元動画像を得る方法 (7) も提案されている が，実画像に適用するには計算コストが高く，汎用計算機 での処理は困難と考えられる。

本論文では, 多重解像度ウェーブレット解析による静止 画像復元手法 ${ }^{(3)}$ を動画像復元に応用し, 解像度低下や焦点 ずれなどの劣化に対する手法を検討する。文献 (3) の手法 は, 画像の持つ特徴に適応した復元を実現できる反面, 反 復計算などの高い計算コストを必要とする。このため，劣 化動画像の各フレームにこの手法を適用し復元処理を行う のでは, 計算量は膨大なものとなる。本論文では, 将来的に リモートセンシングや監視システムへの応用を想定し, 動 画像としては固定したカメラで撮影された劣化動画像を考 える。このとき, ある時刻のフレームの画像を復元するの に，それ以前のフレームで得られた復元画像をもとに予測 された画像を利用する効率的な復元手法を提案する。その ために, 動画像のダイナミクスを考慮したモデル化の方法 を提案し，それに基づいた具体的な計算アルゴリズムを明 らかにする。提案手法では各フレームの計算は逐次的に行 われる。人工的に作成した動画像と実動画像について提案 手法を用いた復元計算を行い，その有効性を検証する。 


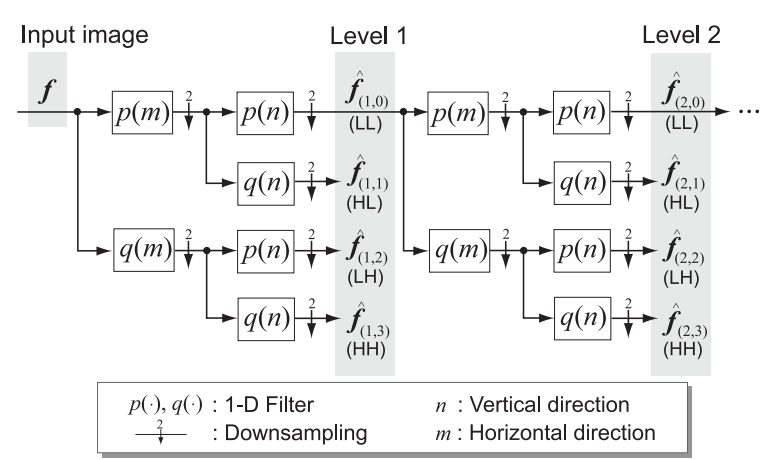

図 1 画像の多重解像度ウェーブレット分解

(MWD)

Fig. 1. Multiresolution wavelet decomposition(MWD) of an image

\section{2. 多重解像度ウェーブレット解析に基づいた静止 画像復元方法}

本章では，提案手法でのベースとして利用する文献 (3) の静止画像復元手法について要約する。

$\langle\mathbf{2} \cdot \mathbf{1}\rangle$ 劣化過程の定式化 一般的な $N \times N$ 画素の静 止画像の劣化過程を

$$
\boldsymbol{g}=\boldsymbol{H} \boldsymbol{f}+\boldsymbol{u}
$$

によって表す ${ }^{(3)}$ 。ただし, $\boldsymbol{g}$ は劣化画像, $\boldsymbol{f}$ は真の画像, $\boldsymbol{H}$ は線形の歪みや解像度の低下，ぼけなどの劣化を表現する 行列, $\boldsymbol{u}$ は加法ノイズである。ここで, $\boldsymbol{g}, \boldsymbol{f}, \boldsymbol{u}$ は 2 次元 配列を辞書的配列順にベクトル化したものである ${ }^{(3)}$ 。2 次 元多重解像度ウェーブレット分解 ${ }^{(4)}$ (以下では MWD とす

る）を用いて，(1) 式を次のように変換する ${ }^{(3)}$ 。

$$
\hat{\boldsymbol{g}}=\hat{\boldsymbol{H}} \hat{\boldsymbol{f}}+\hat{\boldsymbol{u}}
$$

なお，以下で^はMWDにより分解された画像であるこ とを表す。画像 $\boldsymbol{f}$ の MWD のブロック線図を図 1 に示す。 図中の $p(\cdot), q(\cdot)$ はそれぞれ 1 次元のローパス, ハイパス フィルタであり, 入力画像 $\boldsymbol{f}$ から, 水平, 垂直方向にダウ ンサンプルされた 4 種類の分解画像 $\left(\hat{\boldsymbol{f}}_{(1, j)}, j=0\right.$ (LL), 1 $(\mathrm{HL}), 2(\mathrm{LH}), 3(\mathrm{HH}))$ が得られる(3)。さらに，各レベ ルで得られた LL 成分の分解を繰り返すことで，複数の分 解レベルを持つ画像を得ることができる(4)。なお，Lレべ ル MWDにより得られる $\hat{f}$ は次式で定義される。

$$
\hat{\boldsymbol{f}}:=\left(\hat{\boldsymbol{f}}_{(L, 0)}^{T}, \cdots, \hat{\boldsymbol{f}}_{(L, 3)}^{T}, \hat{\boldsymbol{f}}_{(L-1,1)}^{T}, \cdots, \hat{\boldsymbol{f}}_{(1,3)}^{T}\right)^{T}
$$

また，上記の MWD 操作は行列 $\mathcal{W}$ を用いてそれぞれ $\hat{\boldsymbol{g}}=$ $\mathcal{W} \boldsymbol{g}, \hat{\boldsymbol{f}}=\mathcal{W} \boldsymbol{f}, \hat{\boldsymbol{u}}=\mathcal{W} \boldsymbol{u}, \hat{\boldsymbol{H}}=\mathcal{W} \boldsymbol{H} \mathcal{W}^{T}$ で表され，分

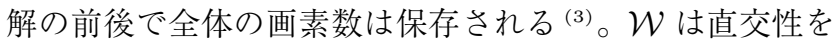
持つため, $\mathcal{W}^{T}$ を用いて分解画像 $\hat{\boldsymbol{f}}$ から元画像 $\boldsymbol{f}$ を得ら れる ${ }^{(3)}$ 。これを多重解像度ウェーブレット再構成（以下で はMWR とする）と呼ぶ。 $\langle 2 \cdot 2\rangle$ 非線形最適化問題と繰り返し計算法

(2) 式の 劣化過程に対する最適な復元画像は, 次の評価関数を $\hat{f} に$ 関して最小化することで得られる ${ }^{(3)}$ 。

$$
\begin{aligned}
J(\hat{\boldsymbol{f}}, \boldsymbol{\lambda})= & \|\hat{\boldsymbol{g}}-\hat{\boldsymbol{H}} \hat{\boldsymbol{f}}\|_{2}^{2}+\lambda_{(L, 0)}\left\|\hat{\boldsymbol{f}}_{(L, 0)}\right\|_{p}^{p} \\
& +\sum_{l=1}^{L} \sum_{j=1}^{3} \lambda_{(l, j)}\left\|\hat{\boldsymbol{f}}_{(l, j)}\right\|_{p}^{p} \ldots \ldots \ldots
\end{aligned}
$$

(4) 式の第 1 項目は復元画像が元の画像に近づくことを要 求し, 第 2 項目以下は各分解画像の $L_{p}$ ノルムが 0 に近づ くことを要求する。ただし， $p$ は真の画像に対する事前モ デルのパラメータであり ${ }^{(3)}, \lambda_{(L, 0)}$ および $\lambda_{(l, j)}$ は正則化 パラメータである。(4) 式による画像復元は正則化手法 ${ }^{(8)}$ の 1 つと捉えることができる。

(4) 式の評価関数 $J(\hat{\boldsymbol{f}}, \boldsymbol{\lambda})$ の $\hat{\boldsymbol{f}}$ に関する微分を $\mathbf{0}$ とおく ことで, 評価関数を最小にする復元画像 $\hat{f}^{*}$ を求める。こ こで, $p \leq 1$ とした場合は，第 2 項目以下にある $L_{p}$ ノル 厶項が微分可能ではなくなるため, 次のように滑らかに近 似する (3)。たとえば $\hat{\boldsymbol{f}}_{(L, 0)}$ は

$$
\left\|\hat{\boldsymbol{f}}_{(L, 0)}\right\|_{p}^{p} \approx \sum_{i}\left\{\left(\left|\hat{\boldsymbol{f}}_{(L, 0)}(i)\right|^{2}+\beta\right)^{p / 2}-\beta^{p / 2}\right\}
$$

とする。ここで, $\hat{\boldsymbol{f}}_{(L, 0)}(i)$ は $\hat{\boldsymbol{f}}_{(L, 0)}$ の $i$ 番目の要素を表し, $\beta \geq 0$ は安定化定数である ${ }^{(3)}$ 。他の $\hat{\boldsymbol{f}}_{(l, j)}$ も (5) 式と同様 に近似したものを (4) 式に代入し， $\hat{\boldsymbol{f}}$ に関して微分したも のを 0 とおくと次の方程式が得られる ${ }^{(3)}$ 。

$$
\begin{aligned}
& \left(\hat{\boldsymbol{H}}^{T} \hat{\boldsymbol{H}}+\frac{p}{2} \boldsymbol{D}^{*}\right) \hat{\boldsymbol{f}}^{*}=\hat{\boldsymbol{H}}^{T} \hat{\boldsymbol{g}} \cdots \cdots \\
& \boldsymbol{D}^{*}=\operatorname{diag}\left[\frac{\boldsymbol{\lambda}(i)}{\left(\left|\hat{\boldsymbol{f}}^{*}(i)\right|^{2}+\beta\right)^{1-p / 2}}\right]_{i=1}^{N^{2}}
\end{aligned}
$$

$\boldsymbol{\lambda}(i)$ は, 上記の正則化パラメータのうち, 要素 $\hat{\boldsymbol{f}}^{*}(i)$ に対 応する值で構成されるべクトルである ${ }^{(3)}$ 。(6) 式, (7) 式 は $\hat{\boldsymbol{f}}^{*}$ に関して非線形であるため, 解析解を求めることは 困難であるが, Vogel と Omanにより提案された反復計算 法 (9) を適用することで, 次式を用いて計算することができ る(3)。

$$
\begin{aligned}
& \left(\hat{\boldsymbol{H}}^{T} \hat{\boldsymbol{H}}+\frac{p}{2} \boldsymbol{D}^{(k)}\right) \hat{\boldsymbol{f}}^{(k+1)}=\hat{\boldsymbol{H}}^{T} \hat{\boldsymbol{g}} \ldots \ldots \ldots \ldots \\
& \boldsymbol{D}^{(k)}=\operatorname{diag}\left[\frac{\boldsymbol{\lambda}(i)}{\left(\left|\hat{\boldsymbol{f}}^{(k)}(i)\right|^{2}+\beta\right)^{1-p / 2}}\right]_{i=1}^{N^{2}} \ldots \ldots
\end{aligned}
$$

ただし，上付き添字 $(k)$ は反復回数を表す。初期值 $\hat{\boldsymbol{f}}^{(0)}$ は 一般的に劣化画像 $\hat{\boldsymbol{g}}$ とする。ここで, $p \geq 1$ でありかつ $\hat{\boldsymbol{H}}$ がフルランクであれば，(8), (9) 式による反復計算は, 非 線形方程式 (6), (7) の唯一解 $\hat{\boldsymbol{f}}^{*}$ に $k \rightarrow \infty$ で収束するこ とが示されている(10)。

上記の手法の特長は，正則化パラメータ $\lambda_{(l, j)}$ を画像の 持つ性質に応じて適応的に与えることで，輪郭などの局所 
的な特徵を保持しながら劣化要因を除去できる点にある。 文献 (3) では最適な $\boldsymbol{\lambda}$ の推定方法も提案されているが, 本 論文では簡単のため定数として扱う。

\section{3. 動画像復元方法}

〈3・1〉 動画像復元への適用と問題点 本論文では真 の動画像 $\boldsymbol{f}^{[1]} \sim \boldsymbol{f}^{[K]}$ に対する劣化動画像 $\boldsymbol{g}^{[1]} \sim \boldsymbol{g}^{[K]}$ が与え られたとき，劣化動画像から真の動画像を復元する動画像 復元問題について考える。ここで，前章の (8)，(9) 式にお いて $\hat{\boldsymbol{f}}$ の添字 $(k)$ が反復計算の繰り返し番号を表していた のに対し，角括弧の添字 $[k]$ は動画像のフレーム番号を表 すことに注意されたい。

動画像の劣化過程は次の関係式

$$
\boldsymbol{g}^{[k]}=\boldsymbol{H} \boldsymbol{f}^{[k]}+\boldsymbol{u}^{[k]}, \quad k=1, \cdots, K \cdots \cdots
$$

で与えられると仮定する。動画像における劣化要素を表す 行列 $\boldsymbol{H}$ は本来は時変であるが，本研究では変化が十分小 さく，一定值に近似できるとする。さて，一般に(8)，(9) 式はサイズが非常に大きな $\left(\operatorname{order}\left(N^{2}\right)\right)$ 行列の反復計算で あるため, 動画像の各フレームで単純に前節までの算法を 適用しようとすると，非常に高い計算コストが必要となる。 これに対して本研究では, 真の動画像に関して以下のよう な性質を仮定し，計算コストを削減することを考える。

（1）真の動画像は前景と背景により構成される。

（2）背景の変化は十分に遅く，ほぼ静止画像と見なし 得る。

（3）前景の位置の変化は，後述するように，直線運動 や放物運動など既知のダイナミクスで記述できる。 あるいは十分な精度で近似が可能である。

（4）前景の濃淡值の空間的変化は緩やかであり，かつ 形状，大きさおよび姿勢が不変な単一の物体とする。 上記の仮定は，例えば，固定したカメラにより運動物体を 撮影し，焦点ずれや解像度の低下を含む実動画像について， 多くの場合で近似的に成り立つと考えられる。このような 実動画像の例は $4 \cdot 2>$ 節で具体的に示される。

ここで，仮定 (1)，(2) が成立するとき，各フレームに対 する背景の初期推定值には，その直前のフレームでの復元 結果をそのまま利用する方法が考えられる。一方，前景に 関しては，運動のダイナミクスに関する情報（仮定 (3)）と 直前のフレームの復元画像における前景の復元結果から, カルマンフィルタ(11) などを用いることで，前景の新しい 位置が予測できる。

したがって，動画像復元がある程度進んだ段階では，直 前のフレームの復元結果から上のようにして推定した前景 と背景に関する推定画像は真の画像に十分近くなる。よっ てこれらを(8), (9) 式の反復計算における初期值として利 用すれば，反復計算の回数を大幅に減じても良いことが期 待できる。実際，本提案手法では (8), (9) 式の計算を各フ レームについて一度だけ行うことにする。このようにして もただ 1 回の復元計算で良好な復元画像が得られることを，

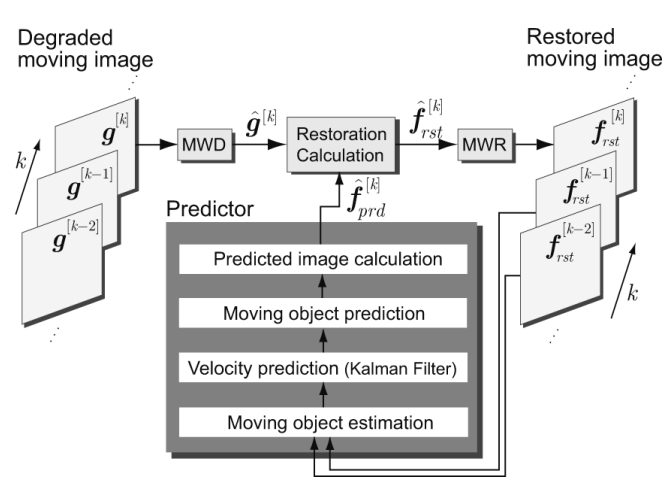

図 $2 k$ フレーム目における提案手法の概要

Fig. 2. Overview of the proposed method at $k$ th frame

表 1 真の動画像に関する記号の定義

Table 1. Definition of variables on an original moving image

\begin{tabular}{lc}
\hline \hline $\boldsymbol{f}^{[k]}$ & Original moving image vector \\
$\boldsymbol{f}_{m d}^{[k]}$ & Moving object domain vector \\
$\boldsymbol{f}_{f g}^{[k]}$ & Foreground moving image vector \\
$\boldsymbol{f}_{b g}$ & Background image vector \\
\hline
\end{tabular}

第 4 章で実験的に検証する。

さて, 以上の考察を元に, 反復計算 $(8),(9)$ 式を

$$
\begin{aligned}
& \left(\hat{\boldsymbol{H}}^{T} \hat{\boldsymbol{H}}+\frac{p}{2} \boldsymbol{D}_{p r d}^{[k]}\right) \hat{\boldsymbol{f}}_{r s t}^{[k]}=\hat{\boldsymbol{H}}^{T} \hat{\boldsymbol{g}}^{[k]} \ldots \ldots \ldots \\
& \boldsymbol{D}_{p r d}^{[k]}=\operatorname{diag}\left[\frac{\boldsymbol{\lambda}(i)}{\left(\left|\hat{\boldsymbol{f}}_{\text {prd }}^{[k]}(i)\right|^{2}+\beta\right)^{1-p / 2}}\right]_{i=1}^{N^{2}} \ldots
\end{aligned}
$$

によって置き換える。(11) 式における $\hat{\boldsymbol{f}}_{r s t}^{[k]}$ はウェーブレッ 卜領域における $k$ フレーム目の復元画像である。(12) 式 における $\hat{\boldsymbol{f}}_{p r d}^{[k]}$ は $k$ フレーム目における初期画像であり, $\langle 3 \cdot 2$ 節以降で示す方法に基づいて $k-1$ フレーム目以前の 復元画像から計算される。以下ではこれを予測画像と呼ぶ。 なお，空間領域における復元画像および予測画像をそれぞ れ $\boldsymbol{f}_{r s t}^{[k]}$ および $\boldsymbol{f}_{p r d}^{[k]}$ で表す。

図 2 に提案手法の概要を示す。劣化画像 $\hat{\boldsymbol{g}}^{[k]}$ に対し, 予 測器 (Predictor) で計算された予測画像 $\hat{\boldsymbol{f}}_{p r d}^{[k]}$ を用いて復元 計算を行い, 復元画像 $\hat{\boldsymbol{f}}_{r s t}^{[k]}$ を得る。なお, 静止画像すな わち $\boldsymbol{g}^{[1]}=\boldsymbol{g}^{[2]}=\cdots$ に対しては, 提案アルゴリズムは文 献 (3) のアルゴリズムと一致する。

〈3・2〉動画像ダイナミクスの定式化 前述の仮定に 基づき, 真の動画像 $\boldsymbol{f}^{[k]}$ のダイナミクスを以下で定式化す る。まず，各記号を表 1 で定義する。運動物体領域べクト ル $\boldsymbol{f}_{m d}^{[k]}$ の各要素は, 背景が運動物体の背後に隠れている部 分を 0 , それ以外を 1 と定義し, 前景べクトル $\boldsymbol{f}_{f d}^{[k]}$ は $\boldsymbol{f}_{m d}^{[k]}$ の 0 と 1 を反転し, 運動物体の真の濃淡值をかけたべクト ルとする。これらの定義より, 真の動画像 $\boldsymbol{f}^{[k]}$ は次式によ り表される。

$$
\boldsymbol{f}^{[k]}=\operatorname{diag}\left(\boldsymbol{f}_{b g}(1), \ldots, \boldsymbol{f}_{b g}\left(N^{2}\right)\right) \cdot \boldsymbol{f}_{m d}^{[k]}+\boldsymbol{f}_{f g}^{[k]}
$$


次に, 運動物体領域 $\boldsymbol{f}_{m d}^{[k]}$ の遷移についての関係式を導入す る。まず，運動物体の特徵点（例えば重心）の運動を

$$
\left[\begin{array}{c}
\boldsymbol{c}^{[k+1]} \\
\boldsymbol{v}^{[k]} \\
\boldsymbol{a}^{[k]}
\end{array}\right]=\left[\begin{array}{ccc}
\boldsymbol{I}_{2} & \boldsymbol{I}_{2} & \boldsymbol{I}_{2} \\
\mathbf{0} & \boldsymbol{I}_{2} & \boldsymbol{I}_{2} \\
\mathbf{0} & \mathbf{0} & \boldsymbol{I}_{2}
\end{array}\right]\left[\begin{array}{c}
\boldsymbol{c}^{[k]} \\
\boldsymbol{v}^{[k-1]} \\
\boldsymbol{a}^{[k-1]}
\end{array}\right]
$$

によって表す。ただし， $c^{[k]}$ は画像上での特徵点位置， $\boldsymbol{v}^{[k]}$ および $\boldsymbol{a}^{[k]}$ は隣接するフレーム間での特徵点の移動量およ び移動量変化を表す。以下では $\boldsymbol{v}^{[k]}$ 拈よび $\boldsymbol{a}^{[k]}$ をそれぞれ 速度および加速度べクトルと呼ぶ。 $\boldsymbol{I}_{2}$ は $2 \times 2$ 単位行列を 表す。(14) 式は 2 次元平面上の等加速度運動を示し, 初期 值の与え方によって, 直線等速度あるいは放物運動などが 記述できる。ただし，ここでは初期值は未知であり，観測 画像から推定されるものとする $(\langle 3 \cdot 3 \cdot 1\rangle,\langle 3 \cdot 3 \cdot 2$ 参照 $)$ 。 また，前節の仮定 $(4)$ より，時間的に相前後する 2 つのフ レームに打ける運動物体領域 $\boldsymbol{f}_{m d}^{[k]}$ と $\boldsymbol{f}_{m d}^{[k+1]}$ の対応する要 素間の移動量はすべて同一であるので, $\boldsymbol{f}_{m d}^{[k]}$ と $\boldsymbol{f}_{m d}^{[k+1]}$ の関 係は

$$
\begin{aligned}
\boldsymbol{f}_{m d}^{[k+1]} & ((n-1) N+m) \\
= & \boldsymbol{f}_{m d}^{[k]}\left(\left[\left\{\left(n-v_{x}^{[k]}\right) \bmod N\right\}-1\right] N\right. \\
& \left.+\left\{\left(m-v_{y}^{[k]}\right) \bmod N\right\}\right) \cdots \ldots \ldots . \\
& (n=1, \cdots, N, m=1, \cdots, N)
\end{aligned}
$$

によって表される。これを行列表現すると，

$$
\boldsymbol{f}_{m d}^{[k+1]}=\boldsymbol{T}\left(\boldsymbol{v}^{[k]}\right) \boldsymbol{f}_{m d}^{[k]}
$$

と書ける。ただし，行列 $\boldsymbol{T}\left(\boldsymbol{v}^{[k]}\right)$ は

$$
\boldsymbol{T}\left(\boldsymbol{v}^{[k]}\right)=\operatorname{diag}\left(\boldsymbol{C}_{y}^{v_{y}^{[k]}}, \ldots, \boldsymbol{C}_{y}^{v_{y}^{[k]}}\right) \cdot \boldsymbol{C}_{x} v_{x}^{[k]}
$$

を表し，以下では遷移行列と呼ぶ。ここで，(17) 式中の行 列 $\boldsymbol{C}_{y}$ は $N \times N$ 次元巡回行列, $\boldsymbol{C}_{x}$ は $N^{2} \times N^{2}$ 次元ブロッ ク巡回行列であり，それぞれ

$$
\begin{aligned}
\boldsymbol{C}_{y} & =\left[\begin{array}{cccccc}
0 & 0 & 0 & \cdots & 0 & 1 \\
1 & 0 & 0 & \cdots & 0 & 0 \\
0 & 1 & 0 & \cdots & 0 & 0 \\
\vdots & \ddots & \ddots & \ddots & \ddots & \vdots \\
0 & \cdots & 0 & 1 & 0 & 0 \\
0 & \cdots & 0 & 0 & 1 & 0
\end{array}\right] \ldots \ldots \\
\boldsymbol{C}_{x} & =\left[\begin{array}{cccccc}
\mathbf{0} & \mathbf{0} & \mathbf{0} & \cdots & \mathbf{0} & \boldsymbol{I}_{N} \\
\boldsymbol{I}_{N} & \mathbf{0} & \mathbf{0} & \cdots & \mathbf{0} & \mathbf{0} \\
\mathbf{0} & \boldsymbol{I}_{N} & \mathbf{0} & \cdots & \mathbf{0} & \mathbf{0} \\
\vdots & \ddots & \ddots & \ddots & \ddots & \vdots \\
\mathbf{0} & \cdots & \mathbf{0} & \boldsymbol{I}_{N} & \mathbf{0} & \mathbf{0} \\
\mathbf{0} & \cdots & \mathbf{0} & \mathbf{0} & \boldsymbol{I}_{N} & \mathbf{0}
\end{array}\right] \ldots
\end{aligned}
$$

のように表される。ここで, $v_{y}^{[k]}=-v_{y}^{\prime[k]}<0$ または $v_{x}^{[k]}=-v_{x}^{\prime[k]}<0$ の場合は

$$
\boldsymbol{C}_{y}^{-v_{y}^{\prime[k]}}:=\left(\boldsymbol{C}_{y}{ }^{-1}\right)^{v_{y}^{[k k]}}, \boldsymbol{C}_{x}^{-v_{x}^{\prime[k]}}:=\left(\boldsymbol{C}_{x}^{-1}\right)^{v_{x}^{\prime[k]}}
$$

と表す。また，前景 $\boldsymbol{f}_{f g}^{[k]}$ の遷移も (16) 式と同様とする。 なお，上記の定式化は前節の仮定 (1)-(4) に基づいてい るため, 複数の運動物体が存在する場合や，運動物体の運 動が平行移動以外の要素を含んだり, 運動領域の形状が変 化する場合，もしくは運動領域の各画素における運動速度 が異なる場合などについては，モデルの拡張が必要であり， 今後の検討課題である。

〈3・3〉 動画像復元における提案アルゴリズム＼cjkstart本論 文で提案する動画像復元アルゴリズムを以下に示す。

(1) $k=1$ に扔ける予測画像 $\hat{\boldsymbol{f}}_{p r d}^{[1]}$ を劣化画像 $\hat{\boldsymbol{g}}^{[1]}$ と抒 き, 式 (12)により $\boldsymbol{D}_{p r d}^{[1]}$ を計算する。式 (11)によ り復元画像 $\hat{\boldsymbol{f}}_{r s t}^{[1]}$ を求め, MWR により $\boldsymbol{f}_{r s t}^{[1]}$ を計算 する。 $k=2$ に抢ける予測画像 $\hat{\boldsymbol{f}}_{r r d}^{[2]}$ を復元画像 $\hat{\boldsymbol{f}}_{r s t}^{[1]}$ とおく。

（2）予測画像 $\hat{\boldsymbol{f}}_{p r d}^{[k]}$ から式 (12)により $\boldsymbol{D}_{p r d}^{[k]}$ を計算し, 式 (11) により復元画像 $\hat{\boldsymbol{f}}_{r s t}^{[k]}$ を求める。MWR によ

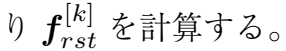

(3) $\boldsymbol{f}_{r s t}^{[k]}$ における運動物体領域の推定画像 $\left(\tilde{\boldsymbol{f}}_{m d}^{[k]}\right.$ とお く) を求め, 前景拉よび背景の推定画像 $\left(\tilde{\boldsymbol{f}}_{f g}^{[k]}, \tilde{\boldsymbol{f}}_{b g}^{[k]}\right.$ とおく）に分割する。

(4) $\tilde{\boldsymbol{f}}_{f g}^{[k]}$ に扔ける特徵点の位置 $\boldsymbol{c}^{[k]}$ 㧍よび速度 $\boldsymbol{v}^{[k-1]}$ を求め，カルマンフィルタにより予測速度 $\overline{\boldsymbol{v}}^{[k]}$ を計 算する。遷移行列 $\boldsymbol{T}\left(\overline{\boldsymbol{v}}^{[k]}\right)$ を(17) 式により計算する。

（5）遷移行列を用いて，前景抄よび運動物体領域の予 測画像 $\overline{\boldsymbol{f}}_{f g}^{[k+1]}, \overline{\boldsymbol{f}}_{m d}^{[k+1]}$ を計算する。背景の予測画像 $\overline{\boldsymbol{f}}_{b g}^{[k+1]}$ は, $k$ フレーム目に扔いて前景に遮蔽されて いない領域では $\tilde{\boldsymbol{f}}_{b g}^{[k]}$ の值を用い, 遮蔽された領域で は遮蔽されていなかったフレームにおける最新の復 元結果を用いる。

(6) ステップ (5) の結果を用いて, 予測画像 $\boldsymbol{f}_{p r d}^{[k+1]}$ (13) 式により計算し，MWDにより $\hat{f}_{p r d}^{[k+1]}$ を求める。

(7) $k=2, \cdots, K$ に関してステップ $(2) \sim(7)$ を繰り 返す。ただし， $k=K$ ではステップ(2)で終了する。 なお，ステップ(1) および (2) で用いられる行列 $\hat{\boldsymbol{H}}^{T} \hat{\boldsymbol{H}}$ は 予め計算しておく。また, ステップ (3) で運動物体領域が 推定されなかったフレームに関しては, 復元画像全体を背 景の推定画像とし，ステップ (4) と (5) における運動物体 領域抢よび前景の予測を省略する。

$\langle\mathbf{3} \cdot \mathbf{3} \cdot \mathbf{1}\rangle$ 運動物体領域の推定 ステップ(3)に扔ける 運動物体領域の推定および前景と背景への分離方法を説明 する。運動領域抽出手法は数多く提案されている(12)(13) が, ここでは以下の簡単な処理により求める。まず, 復元画像 の差分值を閾値処理した画像 $\boldsymbol{f}_{s b}^{[k]}$ を次式により求める。 


$$
\begin{aligned}
& \boldsymbol{f}_{s b}^{[k]}((n-1) N+m) \\
& :=\left\{\begin{array}{lll}
1 & \text { if } & \mid \boldsymbol{f}_{r s t}^{[k]}((n-1) N+m) \\
& & -\boldsymbol{f}_{r s t}^{[k-1]}((n-1) N+m) \mid \geq t h_{1} \\
0 & \text { otherwise }
\end{array}\right.
\end{aligned}
$$

$\boldsymbol{f}_{s b}^{[k]}$ が 1 となる領域から前景が背景を新たに遮蔽した領域 を抽出する。これは仮定 (4) より，前景の濃淡值が空間变 化が緩やかであることを考慮し， $\boldsymbol{f}_{s b}^{[k]}$ が 1 となる領域にお いて，濃淡值の空間変化が小さな領域を抽出することで求 める。遮蔽領域内における任意のピクセル $\left(n_{f}, m_{f}\right)$ と, そ のピクセルを中心とする局所領域の各要素における復元画 像の濃淡值の差の絶対值が閾值以下となるピクセルの集合 を, 運動物体領域の推定画像 $\tilde{\boldsymbol{f}}_{m d}^{[k]}$ とする。すなわち,

$$
\begin{aligned}
& \tilde{\boldsymbol{f}}_{m d}^{[k]}((n-1) N+m) \\
& :=\left\{\begin{array}{ccc}
1 & \text { if } \mid \boldsymbol{f}_{r s t}^{[k]}((n-1) N+m) \\
& -\boldsymbol{f}_{r s t}^{[k]}\left(\left(n_{f}-1\right) N+m_{f}\right) \mid \leq t h_{2} \quad \cdots \\
0 & \text { otherwise }
\end{array}\right.
\end{aligned}
$$

ただし， $(n, m)$ は点 $\left(n_{f}, m_{f}\right)$ を中心とする局所領域内の ピクセルとする。 $\tilde{\boldsymbol{f}}_{m d}^{[k]}$ から, 前景および背景の推定画像を 次式により求める。

$$
\begin{aligned}
& \tilde{\boldsymbol{f}}_{f g}^{[k]}((n-1) N+m) \\
& :=\left\{\begin{array}{rlrl}
\boldsymbol{f}_{r s t}^{[k]} & ((n-1) N+m) \\
& \text { if } & \tilde{\boldsymbol{f}}_{m d}^{[k]}((n-1) N+m)=0 \\
0 & \text { if } & \tilde{\boldsymbol{f}}_{m d}^{[k]}((n-1) N+m)=1
\end{array}\right. \\
& \tilde{\boldsymbol{f}}_{b g}^{[k]}((n-1) N+m) \\
& :=\left\{\begin{array}{c}
0 \quad \text { if } \quad \tilde{\boldsymbol{f}}_{m d}^{[k]}((n-1) N+m)=0 \\
\boldsymbol{f}_{r s t}^{[k]}((n-1) N+m) \\
\quad \text { if } \quad \tilde{\boldsymbol{f}}_{m d}^{[k]}((n-1) N+m)=1
\end{array}\right.
\end{aligned}
$$

$\langle\mathbf{3 \cdot 3 \cdot 2 \rangle}$ 運動速度予測次に, ステップ(4)における 前景の運動速度予測方法を説明する。まず，前景の特徴点 位置として, 重心座標 $\boldsymbol{c}^{[k]}=\left(c_{x}^{[k]}, c_{y}^{[k]}\right)^{T}$ を計算する。

$$
\begin{aligned}
c_{x}^{[k]} & =\frac{\sum_{n=1}^{N} \sum_{m=1}^{N} n \cdot \tilde{\boldsymbol{f}}_{f g}^{[k]}((n-1) N+m)}{\sum_{n=1}^{N} \sum_{m=1}^{N} \tilde{\boldsymbol{f}}_{f g}^{[k]}((n-1) N+m)} \cdots \\
c_{y}^{[k]} & =\frac{\sum_{n=1}^{N} \sum_{m=1}^{N} m \cdot \tilde{\boldsymbol{f}}_{f g}^{[k]}((n-1) N+m)}{\sum_{n=1}^{N} \sum_{m=1}^{N} \tilde{\boldsymbol{f}}_{f g}^{k]}((n-1) N+m)} \cdots
\end{aligned}
$$

特徵点に関する状態方程式および観測方程式を，〈3・2〉で定 義したダイナミクスに基づき次のように定義する。

$$
\left\{\begin{array}{l}
\boldsymbol{\xi}^{[k+1]}=\boldsymbol{F}_{p} \boldsymbol{\xi}^{[k]}+\boldsymbol{G}_{p} \boldsymbol{w}^{[k]} \\
\boldsymbol{y}^{[k]}=\boldsymbol{H}_{p} \boldsymbol{\xi}^{[k]}+\boldsymbol{n}^{[k]}
\end{array}\right.
$$

各变数と行列は特徴点の等加速度運動を考慮し，次のよう に与える。

$$
\begin{aligned}
\boldsymbol{\xi}^{[k]} & =\left[\boldsymbol{c}^{[k]^{T}}, \boldsymbol{v}^{[k-1]^{T}}, \boldsymbol{a}^{[k-1]^{T}}\right]^{T} \ldots \\
\boldsymbol{y}^{[k]} & =\left[\boldsymbol{c}^{[k]^{T}}, \boldsymbol{v}^{[k-1]^{T}}\right]^{T} \ldots \ldots \ldots \ldots \\
\boldsymbol{F}_{p} & =\left[\begin{array}{ccc}
\boldsymbol{I}_{2} & \boldsymbol{I}_{2} & \boldsymbol{I}_{2} \\
\mathbf{0} & \boldsymbol{I}_{2} & \boldsymbol{I}_{2} \\
\mathbf{0} & \mathbf{0} & \boldsymbol{I}_{2}
\end{array}\right], \boldsymbol{G}_{p}=\boldsymbol{I}_{6} \\
\boldsymbol{H}_{p} & =\left[\begin{array}{ccc}
\boldsymbol{I}_{2} & \mathbf{0} & \mathbf{0} \\
\mathbf{0} & \boldsymbol{I}_{2} & \mathbf{0}
\end{array}\right] \ldots \ldots \ldots
\end{aligned}
$$

システム雑音 $\boldsymbol{w}^{[k]}$, 観測雑音 $\boldsymbol{n}^{[k]}$ はそれぞれ平均 $\mathbf{0}$ で既 知の共分散行列

$$
E\left\{\left(\begin{array}{l}
\boldsymbol{w}^{[k]} \\
\boldsymbol{n}^{[k]}
\end{array}\right)\left(\boldsymbol{w}^{\left[k^{\prime}\right]^{T}} \boldsymbol{n}^{\left[k^{\prime}\right]}\right)\right\}=\left(\begin{array}{cc}
\boldsymbol{Q} & \mathbf{0} \\
\mathbf{0} & \boldsymbol{R}
\end{array}\right) \delta_{k k^{\prime}}
$$

を持つ白色ガウス雑音とする。ただし， $\delta_{k k^{\prime}}$ はクロネッカー の記号 (11) である。初期状態 $\boldsymbol{\xi}^{\left[k_{0}\right]}$ は平均值 $\tilde{\boldsymbol{\xi}}^{\left[k_{0}\right]}$, 共分散 行列 $\boldsymbol{\Sigma}^{\left[k_{0}\right]}$ のガウス確率ベクトルとし,

$$
E\left\{\boldsymbol{\xi}^{\left[k_{0}\right]} \boldsymbol{w}^{[k]^{T}}\right\}=\mathbf{0}, E\left\{\boldsymbol{\xi}^{\left[k_{0}\right]} \boldsymbol{n}^{[k]^{T}}\right\}=\mathbf{0} \ldots
$$

とする。

時刻 $k+1$ の予測值 $\overline{\boldsymbol{\xi}}^{[k+1]}$ をカルマンフィル夕

$$
\begin{aligned}
& \overline{\boldsymbol{\xi}}^{[k+1]}=\boldsymbol{F}_{p}\left(\boldsymbol{I}_{6}-\boldsymbol{K}^{[k]} \boldsymbol{H}_{p}\right) \overline{\boldsymbol{\xi}}^{[k]}+\boldsymbol{F}_{p} \boldsymbol{K}^{[k]} \boldsymbol{y}^{[k]} \\
& \ldots \ldots \ldots \ldots \ldots \ldots \cdots \cdots \cdots
\end{aligned}
$$

により計算することで，予測速度 $\overline{\boldsymbol{v}}^{[k]}$ が求まる。ただし，

$$
\begin{aligned}
\boldsymbol{K}^{[k]}= & \overline{\boldsymbol{\Sigma}}^{[k]} \boldsymbol{H}_{p}^{T}\left[\boldsymbol{H}_{p} \overline{\boldsymbol{\Sigma}}^{[k]} \boldsymbol{H}_{p}^{T}+\boldsymbol{R}\right]^{-1} \ldots \ldots \ldots \\
\overline{\boldsymbol{\Sigma}}^{[k+1]}= & \boldsymbol{F}_{p}\left(\overline{\boldsymbol{\Sigma}}^{[k]}-\overline{\boldsymbol{\Sigma}}^{[k]} \boldsymbol{H}_{p}^{T}\left[\boldsymbol{H}_{p} \overline{\boldsymbol{\Sigma}}^{[k]} \boldsymbol{H}_{p}^{T}+\boldsymbol{R}\right]^{-1}\right. \\
& \left.\cdot \boldsymbol{H}_{p} \overline{\boldsymbol{\Sigma}}^{[k]}\right) \boldsymbol{F}_{p}^{T}+\boldsymbol{G}_{p} \boldsymbol{Q} \boldsymbol{G}_{p}^{T} \ldots \ldots \ldots \ldots \\
\overline{\boldsymbol{\Sigma}}^{\left[k_{0}\right]}= & \boldsymbol{\Sigma}^{\left[k_{0}\right]}
\end{aligned}
$$

である。なお，ステップ (3) で運動物体領域が推定されな かったため予測を省略したフレームの後，予測を再開する フレームにおいては, 状態変数の平均值および共分散行列 を初期状態 $\left(\tilde{\boldsymbol{\xi}}^{\left[k_{0}\right]}, \boldsymbol{\Sigma}^{\left[k_{0}\right]}\right)$ にリセットする。

\section{4. シミュレーションと評価}

提案手法の有効性を検証するため，人工的に作成した劣 化動画像および実劣化動画像に対し復元計算を行い, それ ぞれの結果を評価した。

$\langle\mathbf{4} \cdot \mathbf{1}\rangle$ 人工的な動画像における復元シミュレーション 上空から地上を撮影する際に雲状の物体が通過し，なおか つ大気およびカメラの原因などにより観測画像が劣化した シーンを想定し, $128 \times 128$ 画素, 25 フレームからなる人工 的な劣化動画像を作成した。図 3 に 25 フレーム目における 原画像 (a) および劣化画像 (b) を示す。なお, 図 $3(\mathrm{a})$ の左 


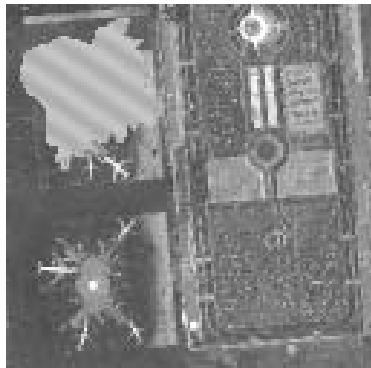

(a) Original image

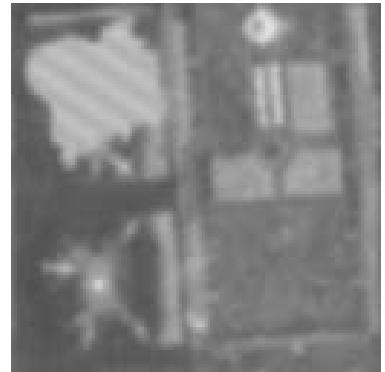

(b) Degraded image
図 325 フレーム目の原画像および劣化画像

Fig. 3. Original and degraded images of 25th frame

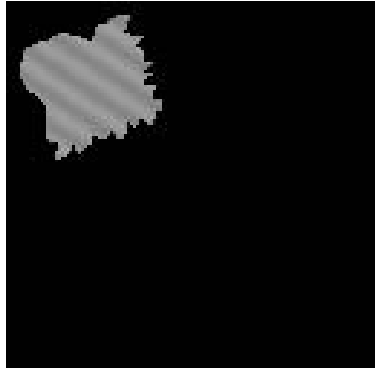

(a) Foreground of the 1st frame

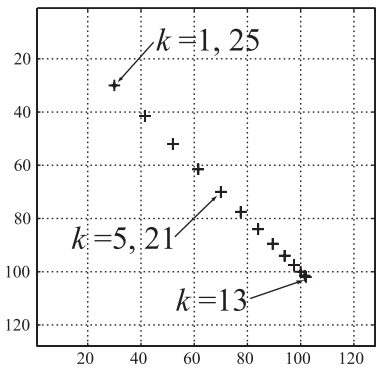

(b) Trajectory of the center of mass
図４１フレーム目の前景と重心の運動軌跡

Fig. 4. Foreground of 1st frame and the trajectory of its center of mass

上に見られる波状の部分が移動物体を表す。図 3(b) は (a) と比較して細かいパターンが失われていることが分かる。

劣化要素としては焦点ずれを考慮し, 点拡がり関数は $\sigma^{2}=1.4$ の 2 次元ガウス関数とした。 $\boldsymbol{H}$ にはこの関数 を $9 \times 9$ 要素で離散化したものを用いた。また，加法ノイズ $\boldsymbol{u}^{[k]}$ は時間および空間に関して平均 $0, \mathrm{SN}$ 比 $25[\mathrm{~dB}]$ のガ ウス雑音とした。背景には標準画像 LAX $128 \times 128$ 画素 に縮小したものを用い, 前景は濃淡值がある方向に関して 緩やかに変化するパターンを持つ任意形状の物体とし, 加 速度 $\boldsymbol{a}^{[k]}=\boldsymbol{a}=(-0.5,-0.5)^{T}$, 初期速度 $\boldsymbol{v}^{[1]}=(12,12)^{T}$ および初期位置 $\boldsymbol{c}^{[1]}=(30,30)^{T}$ で一定の姿勢で等加速度 運動するとした。図 4(a)に1 フレーム目における前景を， (b) には前景の重心位置の軌跡を示す。前景は 13 フレーム 目まで減速しながら左上から右下へ運動し，14 フレーム目 から 25 フレーム目までは逆向きに加速しながら運動する。 計算に用いたパラメータを表 2 にまとめる。MWD のレ ベル $L$ は 3 とし，MWD および MWR には Daubechies の 3 タップウェーブレット(14)を用いた。正則化パラメー 夕 $\lambda_{(l, j)}$ は最も高い分解レベル $L$ の LL 成分におけるパラ メータを $\lambda_{1}$, 他の 3 成分のパラメータを $\lambda_{2}$ とし, 他のレ ベルのパラメー夕は分解レベルが下がるにつれて指数的に 増加するように設定した ${ }^{(3)}$ 。式では次のように表される。

$$
\begin{gathered}
\lambda_{(3,0)}=\lambda_{1}, \lambda_{(l, j)}=\lambda_{2} 2^{-\alpha(l-3)} . \\
(l=1,2,3, \quad j=1,2,3)
\end{gathered}
$$

表 2 シミュレーションに用いたパラメータ

\begin{tabular}{|c|c|}
\hline item name & value \\
\hline Level of MWD $(L)$ & 3 \\
\hline Regularization parameters $\left(\lambda_{1}, \lambda_{2}\right)$ & $(0.1,0.15)$ \\
\hline Regularization parameter $(\alpha)$ & 1.2 \\
\hline Prior model parameter $(p)$ & 1.4 \\
\hline Norm approximation parameter $(\beta)$ & $10^{-2}$ \\
\hline Thresholds of foreground extraction $\left(t h_{1}, t h_{2}\right)$ & $(25,25)$ \\
\hline Mean of initial state $\left(\tilde{\boldsymbol{\xi}}^{\left[k_{0}\right]}\right)$ & 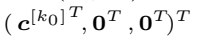 \\
\hline Covariance of initial state $\left(\boldsymbol{\Sigma}^{\left[k_{0}\right]}\right)$ & $\boldsymbol{I}_{6}$ \\
\hline Noise covariances $(\boldsymbol{Q}, \boldsymbol{R})$ & $\left(\boldsymbol{I}_{6}, \boldsymbol{I}_{4}\right)$ \\
\hline
\end{tabular}

Table 2. Parameters used in the simulation

$\lambda_{1}, \lambda_{2}$ は復元画像と真値との誤差の平均值が小さくなるよ うに選び表中の值とした。 $\alpha$ と $p$ は画像の特性を考慮して 選択する必要があるが(3), ここでも真值との誤差の平均値 が小さくなるように選んだ。また， $\beta$ は (5) 式における近 似精度を決めるパラメータであり, 本シミュレーションで は計算精度と計算速度を考慮し $10^{-2}$ とした。な扔，これ らのパラメータは, 本シミュレーションで用いた以外の動 画像に関しても同等の性能が得られた。運動物体領域推定 の間值 $\left(t h_{1}, t h_{2}\right)$ は前景の濃淡值から決定し, 運動物体予 測における初期状態の平均值と共分散行列ならびにノイズ の共分散行列は一般的な值として, 表中の数值を選択した。

上記の設定の下で提案手法による復元処理を行った。同 時に, 提案手法の効果を評価するため, 予測画像として, 前 景のダイナミクスを利用しないで得られる以下の画像を与 え，(11), (12) 式の復元計算を行った場合の復元画像を計 算し，提案手法の結果と比較した。

- 現在のフレームの劣化画像 (比較対象 1)

・直前のフレームの復元画像（比較対象 2)

また，参考のため，

・文献 (3) の方法で各フレームに関して式 (8) および式 (9)の最適化計算を行った場合

との比較も行った。この方法では，kフレーム目における $l^{\prime}$ 回反復後の復元画像 $\left(\hat{\boldsymbol{f}}_{r s t}^{k]}\left(l^{\prime}\right)\right.$ とおく) の収束判定を次式 により行った ${ }^{(3)}$ 。

$$
\left\|\hat{\boldsymbol{f}}_{r s t}^{[k]\left(l^{\prime}\right)}-\hat{\boldsymbol{f}}_{r s t}^{[k]\left(l^{\prime}-1\right)}\right\| /\left\|\hat{\boldsymbol{f}}_{r s t}^{[k]\left(l^{\prime}-1\right)}\right\|<10^{-5}
$$

各計算には CPU が Pentium4 (3.4[GHz])，メモリ1[GB] の計算機を使用し，開発言語には Matlab 用いた。なお， (11) 式または (8) 式の計算には共役勾配法 ${ }^{(15)}$ を用い，そ れぞれ相対残差が $10^{-6}$ を下回るまで計算を行った。

$\langle\mathbf{4} \cdot \mathbf{1} \cdot \mathbf{1}\rangle$ シミュレーション結果の評価まず, 表 $3 に$, 各手法による復元結果の比較を示す。 2 行目に, 復元画像 に対する評価関数值の 25 フレームに扔ける平均值を示す。 なお， $k$ フレーム目での各復元画像に対する評価值は

$$
\begin{aligned}
J\left(\hat{\boldsymbol{f}}_{r s t}^{[k]}, \boldsymbol{\lambda}\right)= & \left\|\hat{\boldsymbol{g}}^{[k]}-\hat{\boldsymbol{H}} \hat{\boldsymbol{f}}_{r s t}^{[k]}\right\|_{2}^{2}+\lambda_{(L, 0)}\left\|\hat{\boldsymbol{f}}_{r s t(L, 0)}^{[k]}\right\|_{p}^{p} \\
& +\sum_{l=1}^{L} \sum_{j=1}^{3} \lambda_{(l, j)}\left\|\hat{\boldsymbol{f}}_{r s t(l, j)}^{[k]}\right\|_{p}^{p} \ldots(38)
\end{aligned}
$$


表 3 各手法での復元結果の比較

Table 3. Comparison of each restoration result

\begin{tabular}{|c|c|c|c|c|}
\hline & Proposed & Compared 1 & Compared 2 & Method of (3) \\
\hline Average cost value of the restored images $\left(\times 10^{5}\right)$ & 1.10 & 1.13 & 1.12 & 1.07 \\
\hline Average ISNR $[\mathrm{dB}]$ & 2.286 & 2.198 & 2.236 & 2.301 \\
\hline Total iteration number of times & 25 & 25 & 25 & 350 \\
\hline Average iteration number of times per a frame & 1 & 1 & 1 & 14 \\
\hline Total calculation time & $22^{\prime} 43^{\prime \prime}$ & $21^{\prime} 45^{\prime \prime}$ & $18^{\prime} 41^{\prime \prime}$ & $5: 55^{\prime} 20^{\prime \prime}$ \\
\hline Total prediction time (within total calculation time) & $7 " 19$ & - & - & - \\
\hline
\end{tabular}

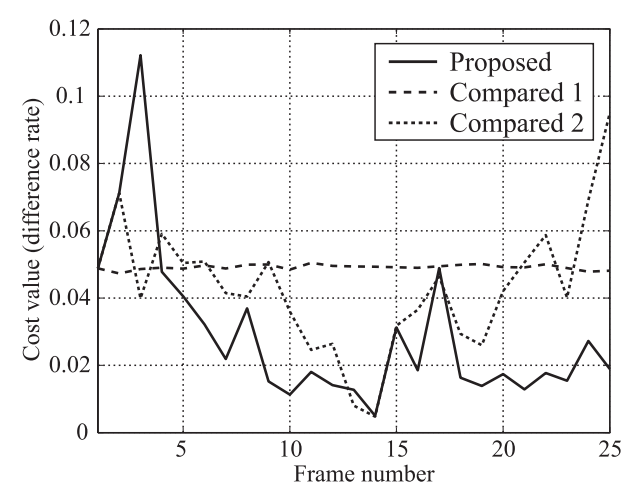

図 5 各手法における復元画像の評価值と文 献 (3) の方法による復元画像の評価值との差の, 文献 (3) の方法による評価值に対する割合

Fig. 5. Difference rate of the cost value of the restored images by each method and the method of (3)

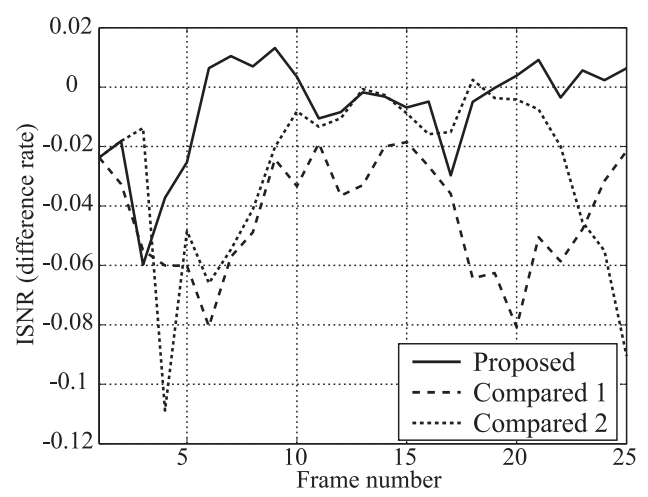

図 6 各手法での復元結果における ISNR と文 献 (3) の方法による復元結果における ISNR との 差の, 文献 (3) の方法による ISNR に対する割合 Fig. 6. Difference rate of ISNR of the restored images by each method and the method of (3)

により計算した。前述のように，文献 (3) の方法による評価 值は最適化計算を行った結果であるため，ほぼ大域的な最小 值を与えるものである。したがって，他の手法による復元結 果の評価值が文献 (3) の方法による評価值に近いほど正解 に近いといえる。表より，提案手法による評価值は，比較対 象 1,2 による評価值と比べ文献 (3) の方法による数值に最 も近いことが分かる。3 行目には, 真の動画像との誤差を評 価するため，各手法による ISNR(Improved Signal-Noise
Ratio)の平均值を示す。ISNR は,

$$
\operatorname{ISNR}\left(\boldsymbol{f}_{r s t}^{[k]}\right)=10 \log _{10} \frac{\left\|\boldsymbol{g}^{[k]}-\boldsymbol{f}^{[k]}\right\|^{2}}{\left\|\boldsymbol{f}_{r s t}^{[k]}-\boldsymbol{f}^{[k]}\right\|^{2}}[\mathrm{~dB}] \cdots
$$

により計算した ${ }^{(16)}$ 。つまり，ISNRの值が大きいほど良い 画像復元がなされたことを示す。ISNR の平均值は文献 (3) の方法を除いて提案手法が最も高く, 比較対象 1,2 の数值 はそれよりも低い。さらに，提案手法および比較対象 1,2 では各フレームにつき一回しか復元計算を行わなかったた め, 総計算時間はほぼ同じあった。一方で, 文献 (3) の方 法による計算結果は非常に長い。総計算時間のうち，提案 アルゴリズムのステップ (3) から (6) までに要した時間を 予測時間として 7 行目に示す。他の手法ではこれらの処理 を行わないため, 表中では一で示している。提案手法の予 測時間は 7 秒程度であり, 総計算時間と比べ十分に短い。

図 5 には，各手法における復元画像の評価值と文献 (3) の方法による復元画像の評価值との差を, 文献 (3) の方法 による評価值で割ったものを示す。図の横軸はフレーム番 号である。前述のように, 文献 $(3)$ の方法は最適な計算結果 のため, 図中での数值が $0 に$ 近いほど最適解に近いことに なる。提案手法および比較対象 1,2 の文献 (3) の方法に対 する評価值の差の割合はいずれも小さいものの, 提案手法 の評価值は多くのフレームで比較対象よりも優れているこ とが分かる。後述するように，これらのフレームは予測が 成功したフレームに対応していることから, 運動物体予測 を行ったことで, 比較対象と比べ文献 (3) の方法に近い評 価值が得られたと考えられる。また，14，15 フレーム目で は前景の運動速度が小さく, 予測を行わなかったため, 提 案手法の評価值は比較対象 2 のもの一致している。

次に，各手法による ISNR と文献 (3) の方法による ISNR の差を, 文献 (3) の方法による ISNR で割ったものを図 6 に示す。困中での数值が 0 に近いほど, 文献 (3) の方法に よる ISNR に近いといえる。図 6 も, 図 5 と同様の傾向を 示している。すなわち, 提案手法の数值は初期フレームお よび $13,17,18$ フレーム目以外では文献 $(3)$ の方法による 数值に最も近いことが分かる。

続いて, 図 7 には垂直方向 (a) および水平方向 (b) の速 度予測結果を示す。前述のように 13,14 フレーム目では 前景の予測を行なっていないため，值を持たない。このた め, 予測を再開する 15 フレーム目ではく $3 \cdot 3 \cdot 2$ 〉における状 態変数を初期化して処理を行った。各方向とも初期状態か 


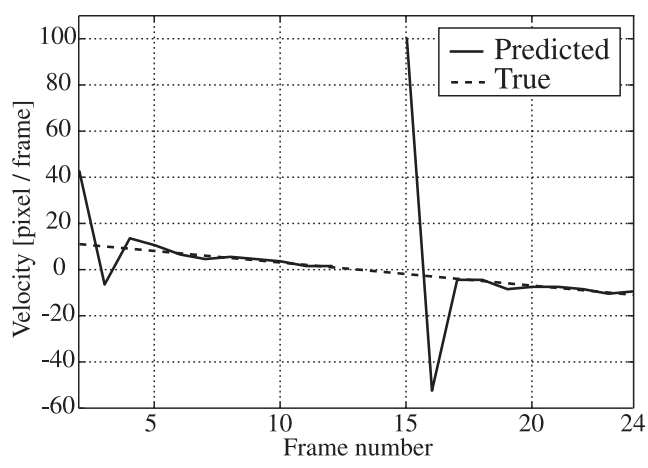

(a) Vertical direction

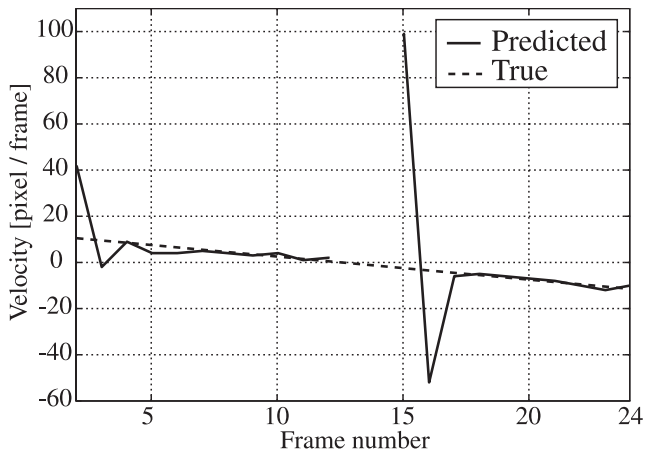

(b) Horizontal direction

図 7 各方向に抒ける運動物体の重心の予測速度 Fig. 7. Predicted velocity of the center of mass of the moving object

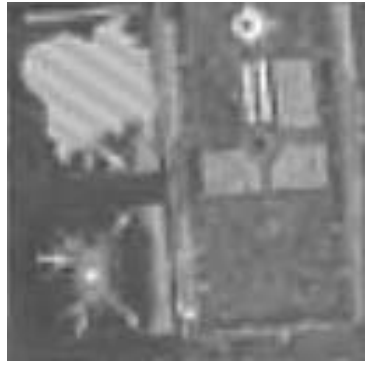

(a) 25th frame

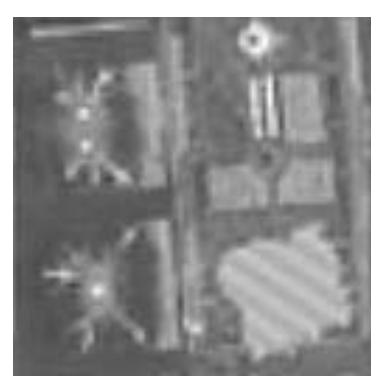

(b) 10th frame
図 8 提案手法による復元画像

Fig. 8. Restored images of the proposed method

ら予測を開始した直後の数フレームでは大きな誤差が見ら れるが，その他のフレームでは真の速度（破線）にほぼ追 従している。したがって，多くのフレームで前景の予測が 正しく行われたことが裏付けられる。

さらに，提案手法に打ける 25 フレーム目 (a) および 10 フレーム目 (b) での復元画像を図 8 に示す。劣化画像（図 3(b)）と比較して，図 8(a) の復元結果は焦点ずれ劣化拈よ び雑音がある程度まで除去され，真の画像（図 3(a)）に近 づいたことが分かる。また，図 8(b)より，10 フレーム目 についても同様の品質であることが分かる。

文献 (3) の方法による最適計算結果と提案手法における 復元画像との主観的な比較を行うため, 図 9 に 25 フレーム 目に扔ける文献(3)の方法による復元結果（図 9(a)）および

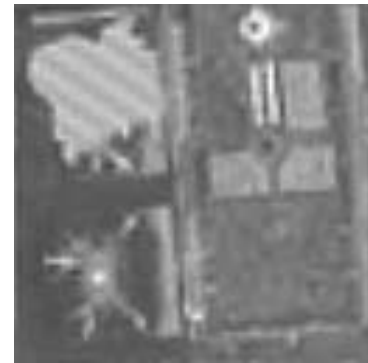
Belge et al.'s method ${ }^{(3)}$

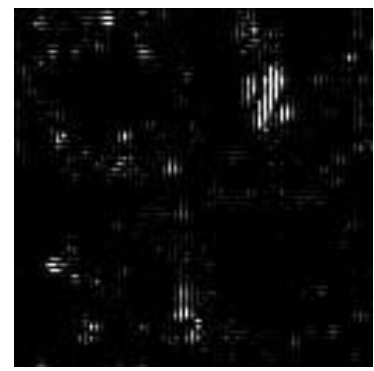

(c) Squared error of the compared (d) Squared error of the compared method 1 and method of (3)

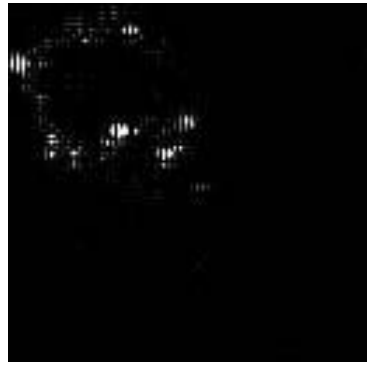

(b) Squared error of the proposed method and method of (3)

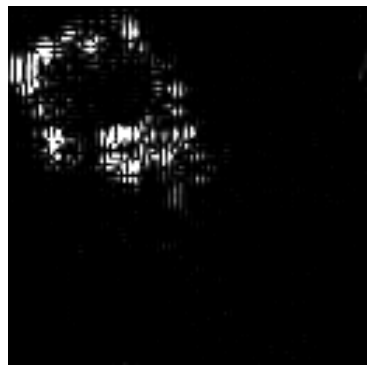

method 2 and method of (3) (a) Restored image by method of

図 925 フレーム目における文献 (3) の方法によ る復元画像および各手法の復元画像との 2 乗誤差

Fig. 9. Restored imege of the method by (3) and its squared error of each restored image of $25 \mathrm{th}$ frame

各手法の復元結果との 2 乗誤差画像（図 9(b)-(d)）を示す。 2 乗誤差画像は $[0,100]$ の範囲を濃淡で表現しており, 数値 が 100 に近いほど白色に近い。前述の理由から，各図にお ける誤差が小さいほど最適な画像に近いといえる。比較対 象 1 に扔ける誤差（図 9(c)）は画像全体に誤差が認められ る。これは復元計算の初期值に劣化画像を用いたためと考 えられる。一方，比較対象 2 に扔ける誤差（図 9(d)) では 前フレームの復元画像を初期值として用いたため, 背景に 対応する部分の誤差は小さいものの, 運動物体が移動した 部分に関して大きな誤差が見られる。それらに対して，提案 手法に扔ける誤差（図 9(b)）は十分に小さいといえる。な お，上記の傾向は他の多くのフレームについても見られた。

上記の結果から，提案手法に抒いて運動物体予測を行っ た結果, 短時間での計算により最適な計算結果に近い復元 動画像を得られたと結論付けられる。

$\langle 4 \cdot 2\rangle$ 実画像における実験 次に，実画像を用いて 行った復元結果を示す。固定した CCD ビデオカメラにより, 光学的に焦点がほけた劣化動画像を撮影し（運動物体によ る流れ劣化は含まない), (10) 式の劣化モデルを適用して提 案手法により復元実験を行った。なお，動画像は $128 \times 128$ 画素，40 フレームとした。3，21 㧍よび 38 フレーム目の劣 化画像を図 10 左列に示す。本動画像は, 前景（中央の車両） に濃淡值が急激に変化する部分が含まれている点および前 景の大きさが微小に変化し平行移動以外の要素を含んでい る点に扔いて，厳密には本手法に扔ける仮定を満たしては 


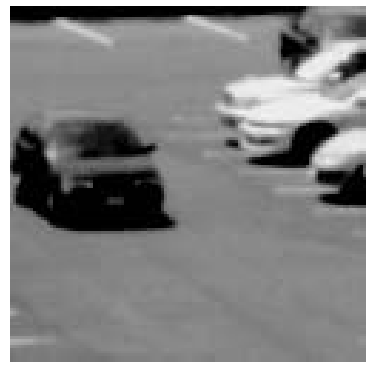

(a) Degraded image (3rd)

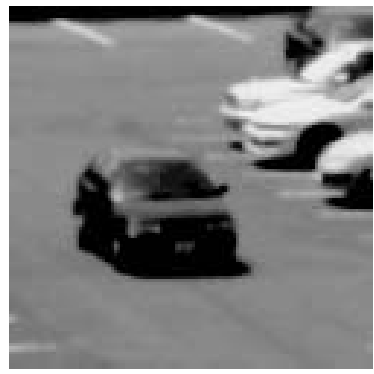

(b) Degraded image (21st)

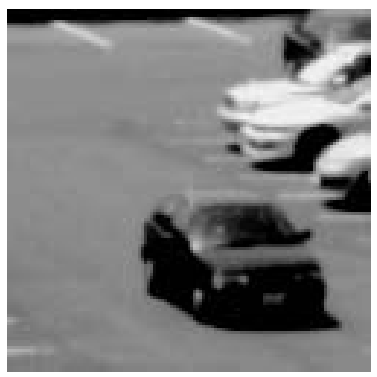

(c) Degraded image (38th)

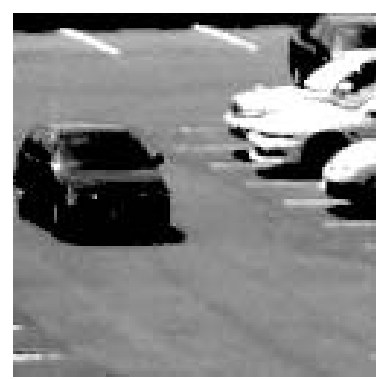

$\left(a^{\prime}\right)$ Restored image (3rd)

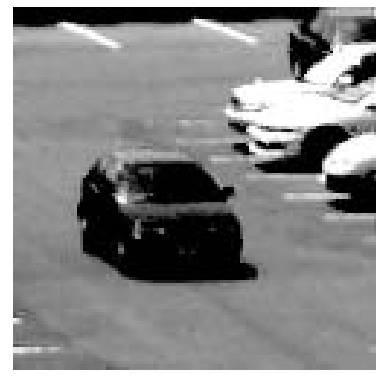

$\left(b^{\prime}\right)$ Restored image (21st)

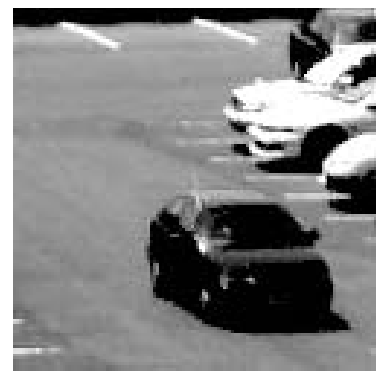

(c') Restored image (38th)
図 10 提案手法による実画像に対する復元結果 $(3,21 ， 38$ フレーム目)

Fig. 10. Restoration results for the real moving image of the proposed method (3rd, 21st and 38th frame)

いない。撮影した動画像の劣化特性は未知であるが，ここ では焦点ずれ劣化を仮定し，点広がり関数として $\sigma^{2}=1.0$ のガウス関数を用いた。なお，この数值および表 2 に対応 するパラメータは，復元画像が主観的に良好となるものを 選択した。

図 10 左列の劣化画像に対し，提案手法により計算した 復元画像を図 10 右列に示す。劣化画像と比較して, 復元 画像は運動している車両や背景の駐車車両，駐車場の白線 などの細かなパターンが鮮明に現れている。また，比較対 象 1 および 2 による復元計算も行った結果, 復元画像の評 価関数值の平均值は，提案手法が $3.03 \times 10^{4}$ であったのに 対し，比較対象 1 および 2 はそれぞれ $3.05 \times 10^{4}$ および $3.74 \times 10^{4}$ であった。したがって，本例のように，劣化特 性が未知であり，提案手法の仮定が近似的にしか満たされ ない劣化動画像に対しても，ガウス関数を点拡がり関数と して適用し，提案手法を用いることで比較対象と比べ良好 な結果を得られることが示された。なお，他の実動画像に 関して行った復元結果についても，上記の例と同様な結果
が得られた。

\section{5. むすび}

本論文では，多重解像度ウェーブレット解析を用いた動 画像復元方式を提案した。動画像のダイナミクスに対する モデル化手法を提案し，それに基ついた具体的な計算アル ゴリズムを与えた。人工的に作成した動画像および実動画 像に対する計算機実験結果から，本手法の有用性を検証し た。本手法は文献 (3) の手法をべースとしているが, 画像の 運動予測手法に関しては文献 (3) とは独立した手法を採っ ている。このため, 他のエッジ保存を目的とする反復画像 復元手法（例として文献 $(2)$ など）にも本手法を適用する ことができると考える。

本論文の提案手法は第 3 節の仮定 (1)-(4) に基づいてい る。しかし，〈4・2 節の例題のように，これらの仮定が必ず しも厳密には満たされず，近似的にしか成り立たない場合 にも良好な復元画像が得られた。近似の程度と復元精度の 関係などについて今後定量的に検討することが必要である。 また，本論文における提案手法の復元計算では，いずれも 焦点ずれ劣化を考慮したが, 解像度の低下などの劣化にも 適用することが可能である。さらに, 劣化要素のオンライ ン推定機構を持たせることで，モーションブラーなどの時 変な劣化を含む動画像についても処理が可能になると考え られるが，今後の課題としたい。

謝 辞

ディスカッションに応じていただいた名古屋大学の宇野 洋二氏ならびに田地宏一氏, 鳥羽商船高専の宮崎 孝氏, 理 化学研究所の天野正輝氏, スズキ（株）の横井 潔氏ならび に（株）デンソーの田代 勉氏に深く感謝致します。

(平成 18 年 6 月 9 日受付, 平成 19 年 2 月 7 日再受付)

\section{文献}

(1) D. Geman and C. Yang: "Nonlinear Image Recovery with Half-Quadratic Regularization", IEEE Trans. Image Processing, Vol.4, No.7, pp.932-946 (1995)

(2) S. Osher, M. Burger, D. Goldfarb, J. Xu, and W. Yin: "An Iterative Regularization Method for Total Variation-Based Image Restoration", Multiscale Modeling \& Simulation, Vol.4, No.2, pp.460-489 (2005)

(3) M. Belge, M.E. Kilmer, and E.L. Miller: "Wavelet Domain Image Restoration with Adaptive Edge-Preserving Regularization", IEEE Trans. on Image Processing, Vol.9, No.4, pp.597-608 (2000)

(4) S. Mallat:"A Theory for Multiresolution Signal Decomposition: the Wavelet Representation", IEEE Trans. on PAMI, Vol.11, No.7, pp.674-693 (1989)

(5) M. Meguro, A. Taguchi, and N. Hamada: "Data-Dependent Weighted Average Filtering for Image Sequence Restoration Trans". IEICE Vol.J82-A, No.10, pp.1623-1632 (1999) (in Japanese)

(6) A. Gangal, T. Kayikçiouglu, and B. Dizdariglu: "An Improved Motion-Compensated Restoration Method for Damaged Color Motion Picture Films", Signal Processing: Image Communication, Vol.19, No.4, pp.353-368 (2004) 
( 7 ) M-C. Hong, M.G. Kang, and A.K. Katsaggelos: "An Iterative Weighted Regularized Algorithm for Improving the Resolution of Video Sequences", Proc. 1997 IEEE International Conf. on Image Processing, pp.II-474-477 (1997)

(8) T. Poggio, V. Torre, and C. Koch: "Computational Vision and Regularization Theory", Naturem Vol.317, pp.314-319 (1985)

(9) C.R. Vogel and M.E. Oman: "Fast, Robust Total VariationBased Reconstruction of Noisy Blurred Images", IEEE Trans. Image Processing, Vol.7, No.6, pp.813-824 (1998)

(10) P. Charbonnier, L. Blanc-Feraud, G. Aubert, and M. Barlaud: "Deterministic Edge-Preserving Regularization in Computed Imaging", IEEE Trans. Image Processing, Vol.6, No.2, pp.298-311 (1997)

（11）片山 徹：「応用カルマンフィルタ」, 朝倉書店 (1983)

(12) S.A. Stansfield: "ANGY: A Rule-Based Expert System for Automatic Segmentation of Coronary Vessels from Digital Subtracted Angiograms", IEEE Trans. PAMI, Vol.8, No.2, pp.188-199 (1986)

(13) L. Vincent and P. Sopille: "Watersheds in Digital Spaces: An Efficient Algorithm Based on Immersion Simulations", IEEE Trans. PAMI, Vol.13, No.6, pp.583-598 (1991)

(14) I. Daubechies: "Ten Lectures on Wavelets", SIAM (1992)

(15) G.H. Golub and C.E. Van Loan: "Matrix Computations, 2nd ed. Baltimore", MD: John Hopkins Univ. Press (1989)

(16) M.R. Banham and A.K. Katsaggelos: "Digital image restoration", IEEE Signal Process. Mag., Vol.14, No.2, pp.24-41 (1997)

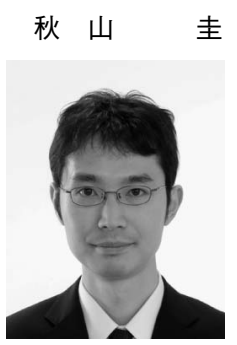

圭（非会員） 2001 年名古屋大学工学部機械・航空 工学科卒業。2003 年同大大学院工学研究科博士 前期課程修了。2004 年理化学研究所バイオ・ミ メティックコントロール研究センター・ジュニア・ リサーチ・アソシエイト。2007 年同大大学院工学 研究科博士後期課程満期退学。同年（株）日立グ ローバルストレージテクノロジーズ入社。在学中 は超並列分散構造を用いた実時間情報処理の研究 に従事。計測自動制御学会，ロボット学会，電子情報通信学会各会員。

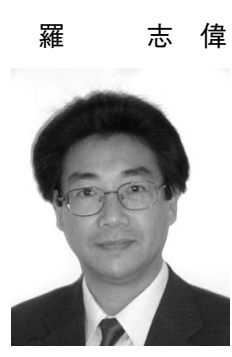

（非会員） 1984 年中国華中工学院自動制御と計 算機学部卒業, 同年中国蘇州大学教師。1986 年 愛知工業大学客員研究員。1992 年名古屋大学大 学院工学研究科博士課程後期課程情報工学専攻修 了, 同年豊橋技術科学大学助手。1994 年理化学 研究所フロンティア研究員, 山形大学工学部助教 授を経て, 現在神戸大学大学院工学研究科情報知 能学専攻教授, 兼理研バイオ・ミメテイックコン トロール研究センター・環境適応ロボットシステム研究チームチーム リーダー。知能ロボット, システム制御工学の研究に従事。博士（工 学)。計測自動制御学会, 日本ロボット学会, IEEE 等各会員。

大 西 正 輝 （正員） 1997 年大阪府立大学工学部情報工学科

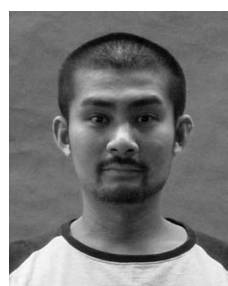
卒業。2002 年同大大学院博士後期課程修了。同 年理化学研究所バイオ・ミメティックコントロー ル研究センター・フロンティア研究員。2006 年 産業技術総合研究所・情報技術研究部門研究員, 現在に至る。理化学研究所客員研究員。ロボット の認知・知識処理に関する研究に従事。博士（工 学)。電子情報通信学会, 日本ロボット学会, 映 像情報メディア学会各会員。

細 江 繁 幸 （正員） 1965 年名古屋大学工学部金属学科卒業。

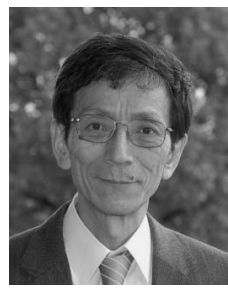
1967 年同大大学院工学研究科博士前期課程修了。 同年名古屋大学工学部助手。同大講師，助教授を 経て 1988 年名古屋大学工学部情報工学科教授。 1993 年同大大学院工学研究科電子機械工学専攻 教授。1999 年理化学研究所バイオ・ミメティック コントロール研究センター・制御系理論研究チー ムチームリーダーを併任。2001 年同研究所セン ター長, 同運動系システム制御理論研究チームチームリーダーを併任, 現在に至る。その間, 制御理論, システム理論などに関する研究に従 事。計測自動制御学会, 電気学会, 機械学会, システム制御情報学会, IEEE 各会員。工博。 